\title{
Optimization of Fibrinolytic Protease Production from Bacillus subtilis I-2 Using Agro-Residues
}

\author{
Bijender Kumar Bajaj*, Satbir Singh, Mowkshi Khullar, Kaurab Singh and Shikha \\ Bhardwaj \\ School of Biotechnology; University of Jammu; Bawewali Rakh; Jammu-India
}

\begin{abstract}
The aim of this work was to study the production of fibrinolytic protease by Bacillus subtilis I-2 on agricultural residues. Molasses substantially enhanced (63\%) protease production (652.32 U/mL) than control $(398.64 \mathrm{U} / \mathrm{mL})$. Soybean meal supported maximum protease production $(797.28 \mathrm{U} / \mathrm{mL})$, followed by malt extract $(770.1 \mathrm{U} / \mathrm{mL})$, cotton cake $(761.04 \mathrm{U} / \mathrm{mL})$, gelatin $(742.92 \mathrm{U} / \mathrm{mL})$ and beef extract $(724.8 \mathrm{U} / \mathrm{mL})$. Based on the Plackett-Burman designed experiments, incubation time, soybean meal, mustard cake and molasses were identified as the significant fermentation parameters. Ammonium sulfate precipitation and DEAE sephadex chromatography resulted 4.8-fold purification of protease. Zymography showed the presence of three iso-forms in the partially purified protease preparation, which was confirmed by the SDS-PAGE analysis (42, 48, $60 \mathrm{kDa})$. Protease exhibited maximum activity at $50^{\circ} \mathrm{C}$ and at $\mathrm{pH}$ 8.0. Significant stability was observed at $30-50^{\circ} \mathrm{C}$ and at $\mathrm{pH} 7.0-10.0 . \mathrm{Mg}^{2+}, \mathrm{Zn}^{2+}, \mathrm{Co}^{2+}$, $\mathrm{Ca}^{2+}, \mathrm{Mn}^{2+}$ and $\mathrm{Cu}^{2+}$, EGTA, EDTA and aprotinin severely decreased the enzyme activity.
\end{abstract}

Key words: Fibrinolytic Protease, Production, Agricultural residues, Bacillus subtilis I-2

\section{INTRODUCTION}

Cardiovascular diseases (CVDs) have emerged as the number one cause of global deaths claiming 17.3 million lives in 2008 and the figure is predicted to rise to 23.6 million by 2030 (Joshi et al. 2008). Thrombosis, manifested in the form of embolism, myocardial infarction, stroke and other cardiac disorders is one of the major causes of CVDs (Mahajan et al. 2012). Under pathophysiological disorders, dynamic balance between the formation and degradation of fibrin is disturbed, leading to accumulation of fibrin causing thrombosis (Simkhada et al. 2010). Therapy for the treatment of acute thrombosis requires intravenous administration of highly specific fibrinolytic agents, which target the preformed fibrin clot hydrolysing the thrombus and restoring the blood flow to the area of ischemia. Although various fibrinolytic agents such as tissue plasminogen activator (t-PA, EC 3.4.21.68), urokinase (u-PA, 3.4.21.73), and bacterial plasminogen activator streptokinase (EC 3.4.24.29) are being extensively investigated (Simkhada et al. 2010) and used widely but most of these thrombolytic agents have got serious limitations such as low fibrin specificity, excessively expensive cost of clinical applications, short half-life, and undesired side effects such as gastrointestinal bleeding, resistance to repercussion and allergic reactions (Mahajan et al. 2012). Therefore, search for novel thrombolytic agents which are safer, costeffective and more efficient is in progress.

*Author for correspondence: bajajbijenderk@gmail.com 
Enzymes have gained momentum in recent years for therapeutic applications as anticoagulants, oncolytics, thromolytics, anti-inflammatories, fibrinolytics, etc. There are several reports on the isolation and purification of fibrinolytic enzymes with potential thrombolytic applications from various sources such as fermented foods, earthworms and snake venom (Peng et al. 2005). Enormous microbial diversity has been exploited for novel biotechnologically important products, including the potential fibrinolytic proteases with suitability for prospective clinical applications (Mahajan et al. 2012). Furthermore, microbial enzyme production always favours the economy of bulk production (Bajaj et al. 2013). Most of the studies on fibrinolytic proteases involved purification and characterization of enzymes (Mahajan et al. 2012) with relatively a fewer reports on optimization of enzyme production (Mukherjee and Rai 2011). Literature shows that studies on fungal fibrinolytic proteases have been more emphasized than bacterial ones (Simkhada et al. 2010). Biochemical and physiological diversity of bacteria may enhance the scope of targeting better fibrinolytic proteases for potential therapeutic applications. Besides, bacteria grow faster as compared to fungi and can use crude raw material as nutrients, and are easily amenable to genetic manipulations. Substrate being the major cost determining factors for microbial enzyme production, utilization of agroresidues as substrates may help not only in reducing enzyme production cost (Bajaj et al. 2013), but would also lead to valorisation of agro-wastes.

In the current study, production of an efficient fibrinolytic protease from bacterial isolate Bacillus subtilis I-2 was optimized by employing cost-effective agricultural residues as substrates and enzyme was partially purified and characterized.

\section{MATERIALS AND METHODS}

Isolation and Screening of Fibrinolytic Bacteria Soil samples from slaughter-houses, dairy, domestic garbage and compost were enriched in nutrient broth and used for the isolation of fibrinolytic protease producing bacteria (Bajaj et al. 2013). Screening of the bacterial isolates was accomplished at primary and secondary levels. In the primary screening, each isolate was examined for proteolytic activity on skimmed milk agar
(SKMA) plates containing skimmed milk powder $(0.5 \%, \mathrm{w} / \mathrm{v})$ and agar $(2 \%, \mathrm{w} / \mathrm{v})$ by spot and well assay (Bajaj and Sharma 2011). Bacterial isolates, which exhibited proteolytic activity, were subjected to secondary screening on fibrin plate to ascertain their fibrinolytic activity. Fibrinolytic activity was determined by the method of Astrup and Mullertz (1952) with slight modifications. The fibrin-agarose gel was prepared, which contained agarose $(1 \%, \mathrm{w} / \mathrm{v})$, fibrinogen $(7.0 \mathrm{mg} / \mathrm{mL})$ and thrombin $(3.0 \mathrm{U} / \mathrm{mL})$. All the solutions were prepared in normal saline $(0.9 \% \mathrm{NaCl})$. The clot was allowed to set for $30 \mathrm{~min}$ at room temperature. Wells were punctured in the fibrin-agarose gel and crude enzyme (cell-free cultural supernatant obtained after centrifugation of $24 \mathrm{~h}$ cultivated bacteria) was poured at $20 \mu \mathrm{L}$ in each well. Plates were allowed to stand for 2-3 h for fluid to diffuse and then incubated at $37^{\circ} \mathrm{C}$ overnight. Appearance of the clear zone around the wells on fibrin plate was indicative of fibrinolytic activity of the crude enzyme. The bacterial isolate (I-2), which showed the biggest zone of clearance and also produced maximum fibrinolytic protease under submerged fermentation, was selected for further studies. Bacterial isolate (I-2) was identified by biolog analysis at Centre for Instrumentation Facility, University of Delhi, South Campus, New Delhi, India (http://www.south.du.ac.in/cif/).

\section{Fibrinolytic Protease Production}

Submerged fermentation was carried out using the isolate I-2 in protease production medium (PPM), which consisted of $(\%, \mathrm{w} / \mathrm{v})$ glucose 0.5 ; peptone 0.5 ; yeast extract $0.5 ; \mathrm{K}_{2} \mathrm{HPO}_{4} 0.4 ; \mathrm{Na}_{2} \mathrm{HPO}_{4} 0.1$; $\mathrm{MgCl}_{2} 0.01 ; \mathrm{Na}_{2} \mathrm{CO}_{3} 0.6$ at $\mathrm{pH} 7.0$ at $180 \mathrm{rpm}$ and $37^{\circ} \mathrm{C}$ for $10-12 \mathrm{~h}\left(\mathrm{~A}_{600}, 0.9\right)$. This was used as inoculum at $1 \%(\mathrm{v} / \mathrm{v})$ in the production medium (PPM) and fermentation was carried out at 180 rpm and $37^{\circ} \mathrm{C}$. Samples, withdrawn after appropriate time periods, were centrifuged $\left(10,000 \times \mathrm{g}\right.$ for $10 \mathrm{~min}$ at $\left.4^{\circ} \mathrm{C}\right)$ and supernatant was used for assaying the protease activity.

\section{Assay of Protease Activity and Protein Content}

Protease activity was determined by using casein as the substrate according to the method of Gessesse et al. (2003) with minor modifications. Assay mixture containing $0.5 \mathrm{~mL}$ of appropriately diluted enzyme and $0.5 \mathrm{~mL}$ of casein $(0.65 \%$ in phosphate buffer $50 \mathrm{mM}, \mathrm{pH} 7.0$ ) was incubated at $37^{\circ} \mathrm{C}$ for $20 \mathrm{~min}$. The reaction was stopped with $2.5 \mathrm{~mL}$ of trichloroacetic acid (TCA, 5\%, w/v), 
and contents were centrifuged $(10,000 \times \mathrm{g}$ for $15 \mathrm{~min}$ at $4^{\circ} \mathrm{C}$ ), and supernatant was examined spectrophotometrically (UV-1800 Spectrophotometer, Shimadzu, Japan) for tyrosine content at $280 \mathrm{~nm}$ by comparing with tyrosine standard curve. One unit of protease activity was defined as the amount of enzyme required to release $1 \mu \mathrm{g}$ of tyrosine from casein per min under assay conditions.

The protein content of the enzyme preparation was determined by Bradford method using bovine serum albumin (BSA) as standard.

\section{Effect of Carbon and Nitrogen Sources on Protease Production}

The glucose of the PPM was replaced with various crude or refined carbon sources $(0.5 \%$, w/v) such as rice husk, wheat bran, maize bran, starch, sucrose, molasses, rice polish, almond hulls, lactose or fructose. The medium was inoculated with 10-12 h grown culture and fermentation was conducted under shaking at $37^{\circ} \mathrm{C}$. Enzyme was assayed in periodically withdrawn samples. For determining the effect of various nitrogen sources on protease production, nitrogen source of PPM (peptone and yeast extract) was replaced with different refined or crude nitrogen sources (malt extract, corn steep liquor seasame cake, gelatin, soybean meal, cotton cake, casein, beef extract, mustard cake or chicken feathers, $1.0 \%, \mathrm{w} / \mathrm{v}$ ), and fermentation was carried out under shaking at $37^{\circ} \mathrm{C}$. Samples withdrawn periodically were assayed for protease activity.

\section{Selection of Significant Variables by Plackett- Burman Design}

For the selection of the most significant variables for protease production, a variety of carbon sources, inorganic salts, nitrogen sources and cultivation parameters were tested and identified by the Plackett-Burman (PB) designed experiment. A total of six variables (molasses, starch, mustard cake, soybean meal, incubation time, $\mathrm{K}_{2} \mathrm{HPO}_{4}$ ) were selected. Experimental design with the name, symbol code and actual level of variables is shown in Table 1. A set of 12 experiments was generated using the Design Expert 6.0 (Stat Ease, Inc., Minneapolis, USA). The significance level ( $\mathrm{P}$ value) of each variable was determined using Student's t-test.
Table 1 - Experimental range and levels of the independent variables used in Plackett-Burman Design.

\begin{tabular}{|c|c|c|c|c|}
\hline \multirow{2}{*}{ Variables } & \multirow[t]{2}{*}{ Units } & \multirow{2}{*}{$\begin{array}{l}\text { Symbol } \\
\text { code }\end{array}$} & \multicolumn{2}{|c|}{$\begin{array}{c}\text { Experimental } \\
\text { values }\end{array}$} \\
\hline & & & Lower & Higher \\
\hline Molasses & $\mathrm{mL} / \mathrm{L}$ & $\mathrm{A}$ & 5 & 15 \\
\hline Starch & $\mathrm{g} / \mathrm{L}$ & B & 5 & 15 \\
\hline Mustard cake & $\mathrm{g} / \mathrm{L}$ & $\mathrm{C}$ & 5 & 15 \\
\hline Soybean meal & $\mathrm{g} / \mathrm{L}$ & $\mathrm{D}$ & 5 & 15 \\
\hline Incubation time & $\mathrm{h}$ & $\mathrm{E}$ & 24 & 72 \\
\hline $\mathrm{K}_{2} \mathrm{HPO}_{4}$ & $\mathrm{~g} / \mathrm{L}$ & $\mathrm{F}$ & 1 & 10 \\
\hline
\end{tabular}

\section{Purification of the Fibrinolytic Enzyme}

Fibrinolytic protease was partially purified by ammonium sulfate precipitation and ion exchange chromatography (DEAE sephadex A-50). Crude enzyme (culture supernatant) was subjected to ammonium sulfate fractionation (20-90\%). Protein content and enzyme activity of each fraction was determined. Ammonium sulfate precipitated enzyme preparation was collected by centrifugation, re-dissolved in phosphate buffer (0.2 M, pH 8.0), dialysed against the same buffer overnight at $4{ }^{\circ} \mathrm{C}$ and dialysate was applied to DEAE sephadex A-50 column equilibrated with phosphate buffer $(0.2 \mathrm{M}, \mathrm{pH} 8.0)$. Elution was effected with $0.25-1.0 \mathrm{M} \mathrm{NaCl}$ gradient and fractions collected were examined for protease activity and protein content.

\section{Native-Page, Zymography and Sds-Page Analysis}

The polyacrylamide gel was copolymerized with the fibrin substrate and native electrophoresis was performed (Sambrook et al. 1989). After electrophoresis, gel was incubated in phosphate buffer for $1 \mathrm{~h}$ at $37^{\circ} \mathrm{C}$. The gel was stained with Coomassie brilliant blue (CBB) for $30 \mathrm{~min}$ and destained (methanol, glacial acetic acid, distilled water in the ratio of 4.5:1:4.5 (v/v). Sodium dodecyl sulphate polyacrylamide gel electrophoresis (SDS-PAGE) was performed by using the stacking gel at 5\% (w/v) and resolving the gel at $12 \%(\mathrm{w} / \mathrm{v})$ in Tris-Glycine buffer, $\mathrm{pH}$ 8.3. The gel was stained with CBB for $1 \mathrm{~h}$ and destained. The molecular mass of purified enzyme was determined by using a full-range rainbow molecular weight marker (GE Healthcare, USA).

\section{Biochemical Properties of Purified Fibrinolytic Protease \\ The effect of temperature on enzyme activity was studied by assaying the enzyme at $30^{\circ} \mathrm{C}$ to $80^{\circ} \mathrm{C}$ in}


$0.2 \mathrm{M}$ phosphate buffer, $\mathrm{pH}$ 7.4. The thermostability was determined by pre-incubating the enzyme preparation for $60 \mathrm{~min}$ at different temperatures $\left(30-80^{\circ} \mathrm{C}\right)$, and then determining the remaining activity at $\mathrm{pH} 7.4$ and $37^{\circ} \mathrm{C}$. The effect of $\mathrm{pH}$ on enzyme activity was studied by using different $\mathrm{pH}$ buffers (acetate buffer - $\mathrm{pH} 5.0$ and 6.0; phosphate buffer - $\mathrm{pH} 7.0$ and 8.0, and Tris$\mathrm{HCl}$ buffer $-\mathrm{pH} 9.0$ and 10.0). For the measurement of $\mathrm{pH}$ stability, the enzyme was preincubated for $60 \mathrm{~min}$. at $4{ }^{\circ} \mathrm{C}$ at different $\mathrm{pH}$ by using appropriate buffers. The residual activity was then determined at $\mathrm{pH} 7.4$ at $37^{\circ} \mathrm{C}$.

The effect of different metal ions viz. $\mathrm{Fe}^{2+}, \mathrm{Mg}^{2+}$, $\mathrm{Zn}^{2+}, \mathrm{Co}^{2+}, \mathrm{Ca}^{2+}, \mathrm{Mn}^{2+}, \mathrm{Cu}^{2+}$ on the protease activity was determined by including the metal salt in enzyme assay mixture at final concentration of
$2 \mathrm{mM}$. Similarly, ethylene glycol tetraacetic acid (EGTA), ethylenediaminetetraacetic acid (EDTA), and aprotinin were also evaluated for their influence on enzyme activity by including either of them in enzyme assay mixture at concentration of $2 \mathrm{mM}$.

\section{RESULTS}

\section{Fibrinolytic Bacteria}

Among a total of 32 bacterial isolates screened, the isolate I-2 showed maximum fibrinolytic protease activity in plate assay (Fig. 1) as well under submerged fermentation. On the basis of biolog analysis (http://www.south.du.ac.in/cif/), the organism was identified as Bacillus subtilis and designated as B. subtilis I-2.
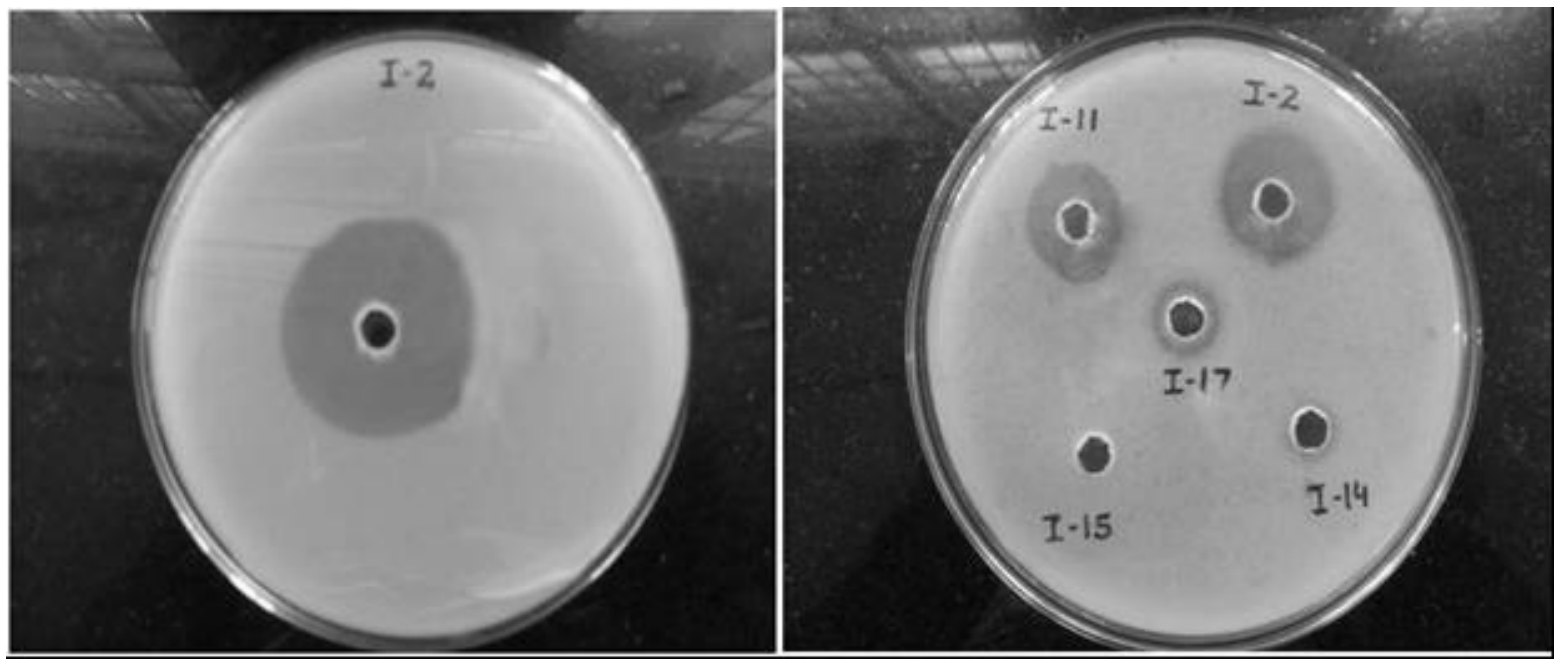

Figure 1 - Screening of bacterial isolates for fibrinolytic activity. Cultural supernatant obtained after centrifugation of $24 \mathrm{~h}$ cultivated bacteria was poured at $20 \mu \mathrm{L}$ in wells punctured in the fibrin-agarose plate (agarose $1 \%$, fibrinogen $7 \mathrm{mg} / \mathrm{mL}$, thrombin $3 \mathrm{U} / \mathrm{mL}$ ). Plates were incubated at $37^{\circ} \mathrm{C}$ overnight and observed for clear zone around the wells which was suggestive of fibrinolytic activity.

\section{Effect of Carbon and Nitrogen Sources on Protease Production}

Among various carbon sources examined for protease production, molasses supported maximum protease yield $(652.32 \mathrm{U} / \mathrm{mL})$, which was substantially higher than control (398.64 $\mathrm{U} / \mathrm{mL})$, and was followed by fructose $(490.5$ $\mathrm{U} / \mathrm{mL}$ ) and starch $(413.13 \mathrm{U} / \mathrm{mL})$ as shown in Figure 2. However, other carbon sources did not perform well. All the ten different agriculture based nitrogen sources though supported appreciable protease production but none was able to induce higher protease production than the control. Soybean meal supported maximum protease production $(797.28 \mathrm{U} / \mathrm{mL})$ and was closely followed by malt extract $(770.1 \mathrm{U} / \mathrm{mL})$, cotton cake $(761.04 \mathrm{U} / \mathrm{mL})$ gelatin $(742.92 \mathrm{U} / \mathrm{mL})$ and beef extract $(724.8 \mathrm{U} / \mathrm{mL})$ as presented in Figure 3. Other nitrogen sources too gave significant protease yield. Protease production was examined at varying concentration of soybean meal, which showed that its $1.0-1.5 \%$ was optimum for protease production. 


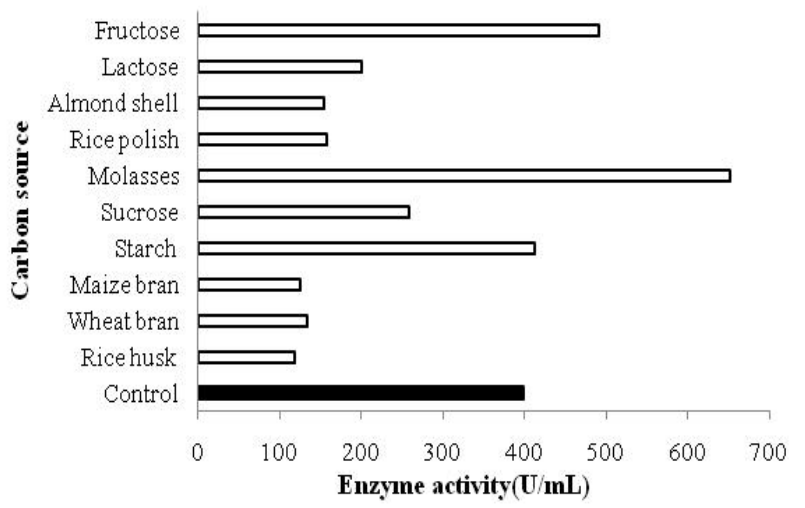

Figure 2 - Fibrinolytic protease production from Bacillus subtilis I-2 using various agriculture based carbon sources. Glucose of protease production medium (control) was replaced with either of carbon source $(0.5 \%, \mathrm{w} / \mathrm{v})$, and fermentation was executed under shaking (180 rpm) at $37^{\circ} \mathrm{C}$.

\section{Selection of Significant Variables by Plackett- Burman Design}

The design matrix selected for the screening of significant variables for protease production and the corresponding responses are shown in Table 2. The adequacy of the model was calculated and the variables showing statistically significant effects

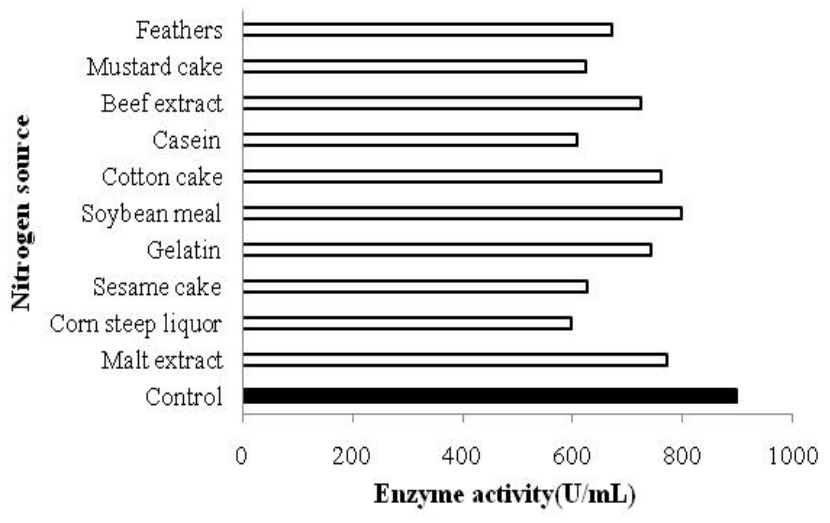

Figure 3 - Fibrinolytic protease production from Bacillus subtilis I-2 using various agriculture based nitrogen sources. Peptone and yeast extract of the protease production medium (control) were replaced with either of nitrogen source $(1 \%, w / v)$, and fermentation was executed under shaking (180 rpm) at $37^{\circ} \mathrm{C}$.

were screened by Student's t-test for ANOVA. Incubation time, with a probability value of 0.0012 , was the most significant factor, followed by soybean meal $(0.0034)$, mustard cake $(0.0076)$, and molasses (0.0488) as depicted in Table 3. The lower probability values indicated the more significant factors for the production of protease.

Table 2 - Plackett-Burman design for selection of significant fermentation variables for protease production from Bacillus subtilis I-2.

\begin{tabular}{ccccccccc}
\hline Run & \multicolumn{9}{c}{ Experimental values } & \multicolumn{2}{c}{ Protease activity (U/mL) } \\
\cline { 2 - 8 } order & A & B & C & D & E & F & Experimental & Predicted \\
\hline 1 & 15 & 5 & 5 & 5 & 72 & 10 & 559.9 & 538.01 \\
2 & 5 & 15 & 15 & 5 & 72 & 1 & 596.14 & 596.60 \\
3 & 5 & 5 & 5 & 5 & 24 & 1 & 396.82 & 390.93 \\
4 & 15 & 15 & 15 & 5 & 72 & 10 & 625.14 & 639.48 \\
5 & 15 & 5 & 15 & 5 & 24 & 1 & 476.55 & 499.65 \\
6 & 5 & 5 & 5 & 15 & 72 & 10 & 541.78 & 579.68 \\
7 & 15 & 15 & 5 & 15 & 24 & 1 & 534.54 & 547.68 \\
8 & 15 & 15 & 5 & 15 & 72 & 1 & 665 & 651.86 \\
9 & 5 & 5 & 15 & 15 & 72 & 1 & 663.19 & 695.52 \\
10 & 5 & 15 & 5 & 5 & 24 & 10 & 436.69 & 426.57 \\
11 & 15 & 5 & 15 & 15 & 24 & 10 & 599.77 & 584.22 \\
12 & 5 & 15 & 15 & 15 & 24 & 10 & 581.65 & 576.97 \\
\hline
\end{tabular}

Table 3 - Results of ANOVA for the Plackett-Burman design.

\begin{tabular}{lccc}
\hline Variables & Mean square & F-value & P-value \\
\hline Molasses & 4986.99 & 6.71 & 0.0488 \\
Starch & 3371.78 & 4.58 & 0.0863 \\
Mustard cake & 13852.29 & 18.65 & 0.0076 \\
Soybean meal & 20393.18 & 27.46 & 0.0034 \\
Incubation time & 32565.63 & 43.84 & 0.0012 \\
$\mathrm{~K}_{2} \mathrm{HPO}_{4}$ & 13.42 & 0.018 & 0.8983 \\
\hline
\end{tabular}

R- squared- 0.9529, Adj. R- squared- 0.8964, C.V.- 4.90 


\section{Purification of Fibrinolytic Enzyme}

Ammonium sulfate fraction precipitated at $60 \%$ saturation exhibited maximum activity and was subjected to DEAE sephadex A-50 chromatography after dialysis, which resulted in purification by 2.3-fold. Subsequent DEAE sephadex A-50 chromatography led to purification by 4.8 -fold, with a recovery of $10.4 \%$ as shown in Table 4.

Table 4 - Purification of fibrinolytic protease from Bacillus subtilis I-2.

\begin{tabular}{lccccc}
\hline Sample & $\begin{array}{c}\text { Total activity } \\
(\mathbf{U})\end{array}$ & $\begin{array}{c}\text { Total protein } \\
(\mathbf{m g})\end{array}$ & $\begin{array}{c}\text { Specific } \\
\text { activity (U/mg) }\end{array}$ & $\begin{array}{c}\text { Purification } \\
\text { fold }\end{array}$ & $\begin{array}{c}\text { Yield } \\
(\%)\end{array}$ \\
\hline $\begin{array}{l}\text { Crude extract } \\
\text { Ammonium sulfate }\end{array}$ & 7840 & 278 & 28.2 & 1 & 100 \\
precipitation (40-60\%) & 2263 & 34.8 & 65 & 2.3 & 28.9 \\
$\begin{array}{l}\text { Dialysis } \\
\begin{array}{l}\text { DEAE-Sephadex A-50 } \\
\text { chromatography) }\end{array}\end{array}$ & 1864.3 & 26.5 & 70.39 & 2.5 & 23.8 \\
\hline
\end{tabular}

\section{Effect of Temperature on Activity and Stability of Protease}

Fibrinolytic protease showed maximum activity at $50^{\circ} \mathrm{C}$; however, considerable activity was observed at $60^{\circ} \mathrm{C}(88.6 \%)$ and at $40^{\circ} \mathrm{C}(68.6 \%)$. But activity at still higher and lower temperatures decreased severely. Thermostability analysis of the protease showed that enzyme was quite stable at $30-50^{\circ} \mathrm{C}$ for $60 \mathrm{~min}$. but at $60^{\circ} \mathrm{C}$ and above activity decreased drastically (Fig. 4).

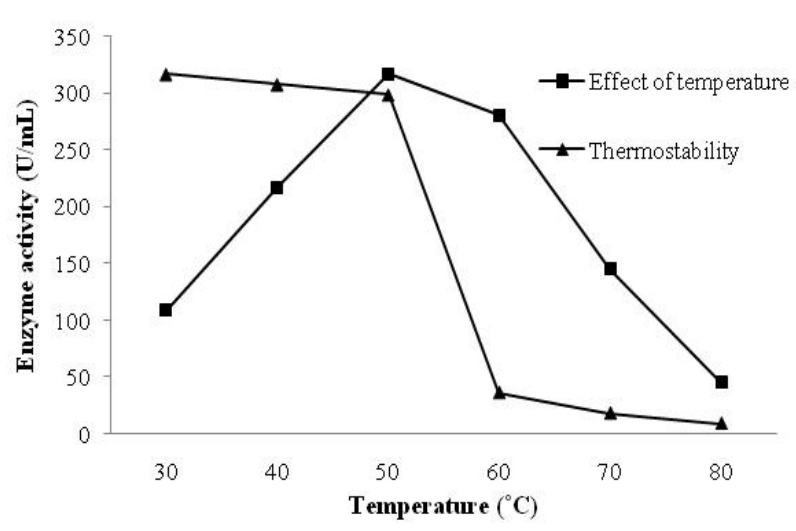

Figure 4 - Activity and stability of protease from Bacillus subtilis I-2 at different temperatures. Protease activity assay was conducted at different temperatures (30$80^{\circ} \mathrm{C}$ ), and thermostability was examined by pre-incubating the enzyme at respective temperatures for $1 \mathrm{~h}$, and then assaying the residual activity.

\section{Effect of pH and pH Stability of Fibrinolytic Protease}

The partially purified enzyme exhibited maximum activity in the $\mathrm{pH}$ range of 7.0-9.0 with optimum at
pH $8.0(407.7 \mathrm{U} / \mathrm{mL})$. Considerable activity was observed at $\mathrm{pH} 10.0(84.4 \%)$ as presented in Figure 5. However, fibrinolytic protease exhibited poor activity in the acidic $\mathrm{pH} 5.0-6.0$ (53-64\%). $\mathrm{pH}$ stability analysis of the protease showed that enzyme possessed remarkable stability at $\mathrm{pH} 7.0$ 10.0 (98.5-100\%). In the acidic $\mathrm{pH}(5.0-6.0)$, the enzyme retained 77 and $85 \%$ activity, respectively (Fig. 5).

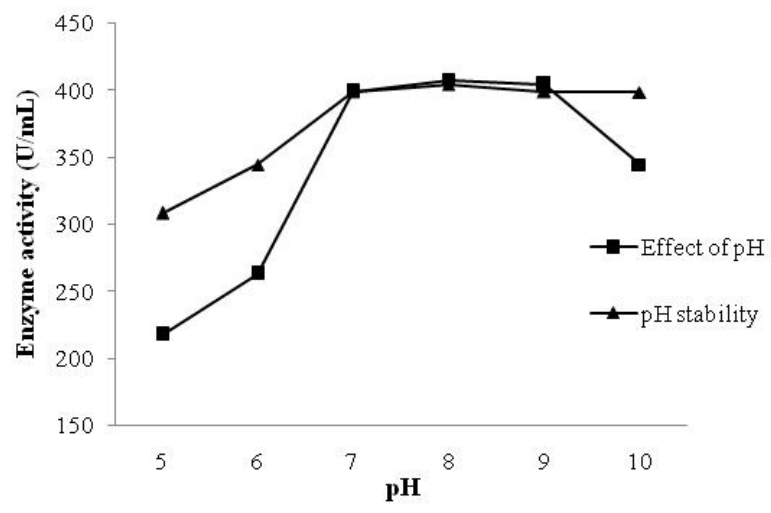

Figure 5 - Activity and stability of protease from Bacillus subtilis $\mathrm{I}-2$ at different $\mathrm{pH}$. Protease activity assay was conducted at different $\mathrm{pH}$ by using appropriate buffers, and $\mathrm{pH}$-stability was determined by preincubating the enzyme at respective $\mathrm{pH}$ for $1 \mathrm{~h}$, and then assaying the residual activity.

\section{Effect of Metal Ions and Additives on Protease Activity}

All the metal ions examined in the present study caused severe activity decrease of B. subtilis I-2 
fibrinolytic protease (52-73.2\%), except $\mathrm{Fe}^{2+}$, which reduced the enzyme activity slightly only. EGTA and aprotinin inhibited the activity more strongly as compared to EDTA (Fig. 6).

\section{Fibrin Zymography and SDS-PAGE}

Native-PAGE analysis of the purified enzyme preparation followed by zymography showed three

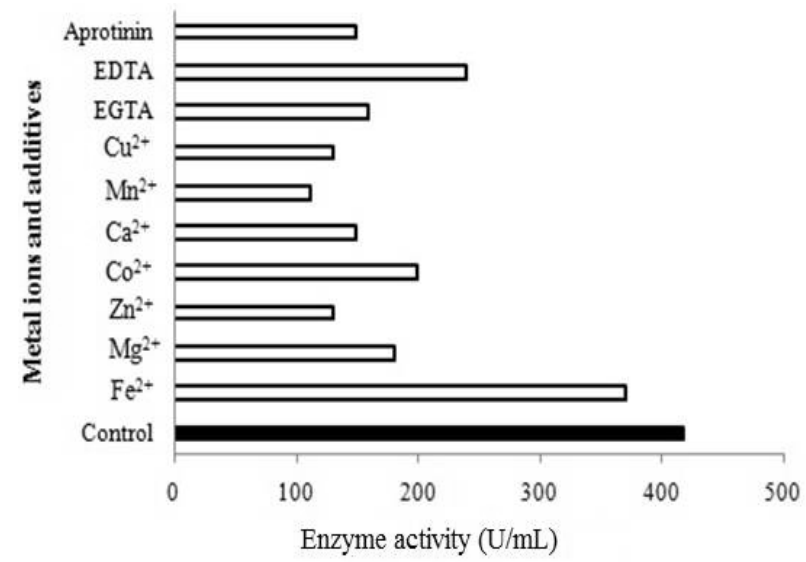

Figure 6 - Effect of metal ions and additives on activity of protease from Bacillus subtilis I-2. Either of the metal ion/additive was included in the enzyme assay mixture at final concentration of $2 \mathrm{mM}$, and protease activity assay was conducted.

\section{DISCUSSION}

Enormous natural microbial diversity has been exploited for the isolation of potential microorganisms for the production of numerous biotechnologically important products, including fibrinolytic proteases (Agrebi et al. 2009; Kim et al. 2011; Bajaj et al. 2013). Uesugi et al. (2011) reported a highly potent fibrinolytic serine protease from Streptomyces omiyaensis isolate, which had about 18 -fold higher activity than that of plasmin.

Economic viability of enzyme production process is necessary considering the huge quantities of enzymes required for the industrial applications. Enzyme overproduction by genetic manipulation and/or culture medium engineering can significantly contribute towards process economy (Bajaj et al. 2013). Substrate cost substantially influences the economy of bulk production of clear bands on the fibrin zymogram, indicating that there were three different proteases with fibrinolytic activity. SDS-PAGE analysis confirmed the fibrin zymography results showing the presence of three protein bands corresponding to molecular weights of approximately 42,48 and $60 \mathrm{kDa}$ (Fig. 7).
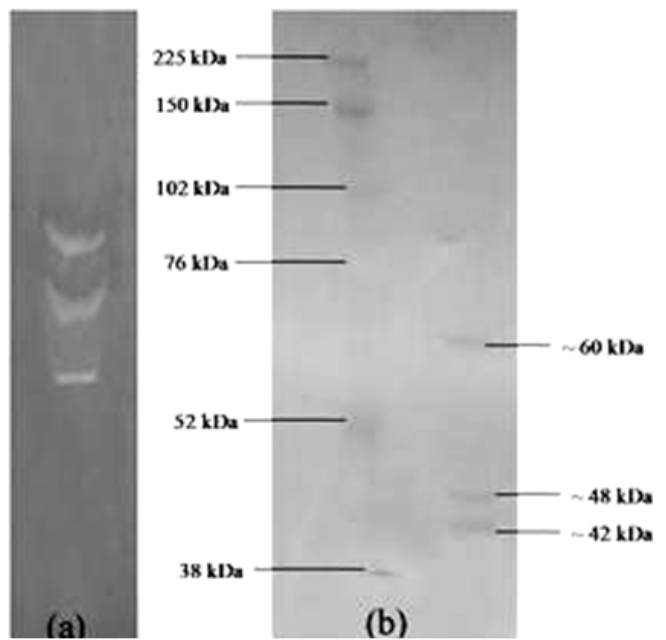

Figure 7 - Zymogram analysis (a) and SDS-PAGE (b) of partially purified protease from Bacillus subtilis I-2. In-gel zymography was done using $0.1 \%$ fibrin. Molecular weight was determined using full-range rainbow molecular weight markers (GE Healthcare, USA).

industrial enzymes. Agricultural residues, available in abundance in India, may serve as lowcost substrates for economical production of enzymes including proteases (Bajaj and Sharma 2011; Bajaj et al. 2012; Bajaj et al. 2013). Extracellular protease production by the microorganisms is strongly influenced by the cultural and environmental variables (Bajaj and Sharma 2011). Generally, the moderately complex substrates serve as conditioned carbon sources for microbial enzyme production realizing the slow release of carbon and obviating the catabolite repression (Bajaj and Singh 2010). In the current study, molasses as carbon source substantially enhanced the protease production $(63 \%)$ by $B$. subtilis I-2, which was in accordance with the results of Qureshi et al. (2011) who showed that $B$. subtilis EFRL 01 produced maximum protease when molasses was used at $1 \%$ as a sole carbon source. Similar results have been obtained by 
others (Calik et al. 2003; Shikha et al. 2007). Molasses, a by-product from sugar industries is rich in nutrients and minerals, and at the same time is cheap and available in plenty, and could be exploited for the production of other industrial products (Bajaj and Sharma 2010). Various crude substrates have been reported to serve as excellent substrates for fibrinolytic protease production from Bacillus spp. (Wang et al. 2009; Agrebi et al. 2010; Bajaj et al. 2013).

The type and availability of nitrogenous precursors in the medium influence the production of extracellular enzymes (Bajaj and Sharma 2011). Besides, nitrogen source can significantly affect the medium $\mathrm{pH}$ during the course of fermentation, which in turn may influence enzyme activity and stability. B. subtilis I-2 successfully utilized various complex low-cost nitrogen sources, viz. soybean meal, cotton seed cake, gelatin, beef and malt extract and produced appreciable titres of fibrinolytic protease. Cotton seed cake enhanced the protease production substantially from $B$. cereus NS-2 (Bajaj et al. 2013). Various complex materials such as yeast extract, soy/casein peptone, soybean powder, shrimp shell powder, etc. have been reported as reasonably good nitrogen sources for protease production from Bacillus spp. (Wang et al. 2008; Wang et al. 2009; Agrebi et al. 2010; Mahajan et al. 2012).

The most effectual fermentation variables, which influence the protease production maximally can be identified by using the traditional 'one-variableat-a-time' approach or by $\mathrm{PB}$ designed experiments (Bajaj and Wani 2011; Mukherjee et al. 2012). Since the PB design study is fast, less laborious, efficient and reliable, is widely preferred choice (Stanbury et al. 1995). Among a total of six fermentation variables examined, four (incubation time, soybean meal, mustard cake and molasses) influenced the protease production maximally by $B$. subtilis I-2. Mukherjee and Rai (2011) explored six fermentation variables by PB designed experiments and reported that three factors, viz. casein, ammonium sulphate and medium $\mathrm{pH}$ stimulated the fibrinolytic protease production by Bacillus sp. strain AS-S20-I. Similarly, four variables (hulled grain of wheat, $\mathrm{NaCl}, \mathrm{K}_{2} \mathrm{HPO}_{4}$ and $\mathrm{KH}_{2} \mathrm{PO}_{4}$ ) were found as the most significant ones among a total of 11 investigated for protease production from $B$. mojavensis A21 by $\mathrm{PB}$ designed experiments (Haddar et al. 2010).
Salt precipitation and chromatography have commonly been employed for the purification of enzymes (Bajaj and Singh 2010; Mahajan et al. 2012). B. subtilis I-2 protease was purified by $4.8-$ fold with a recovery of $10.4 \%$. Wang et al. (2008) purified $B$. subtilis LD-8547 fibrinolytic enzyme by 32.42-fold employing ammonium sulfate precipitation, DEAE-sephadex A50 and gel filtration chromatography with $12.4 \%$ recovery. $B$. subtilis ICTF-1 fibrinolytic enzyme was purified by ammonium sulphate precipitation, sepharose anion exchange and butyl sepharose FF hydrophobic interaction chromatography with a 34.42 -fold increase in specific activity and $7.5 \%$ recovery (Mahajan et al. 2012). B. subtilis I-2 produced three proteases corresponding to molecular weight of 42,48 and $60 \mathrm{kDa}$ as determined by SDS-PAGE. Similar to the present results, $B$. subtilis $\mathrm{P} 13$ has been reported to secrete multiple proteases (Pillai et al. 2011). In contrast however, Streptomyces sp. CS624 (Mander et al. 2011) and Bacillus sp. AS-S20-I (Mukherjee et al. 2012) produced single protease.

B. subtilis $\mathrm{I}-2$ protease showed maximum activity and stability at $50^{\circ} \mathrm{C}$. Several Bacillus spp. fibrinolytic proteases have shown maximum activity at $35-40^{\circ} \mathrm{C}$ (Bajaj et al. 2013). However, temperature optima of fibrinolytic protease from B. subtilis A26 (Agrebi et al. 2009) and Streptomyces sp. CS624 (Mander et al. 2011) was $60^{\circ} \mathrm{C}$. Alkaline protease with fibrinolytic activity from $S$. gulbargensis showed maximum activity at $45^{\circ} \mathrm{C}$ (Vishalakshi et al. 2009). Fibrinolytic proteases from various Bacillus spp. showed thermostability in the range of $40-50^{\circ} \mathrm{C}$ (Agrebi et al. 2010; Bajaj et al. 2013). B. subtilis I-2 protease showed maximum activity at $\mathrm{pH} 8.0$ and stability at $\mathrm{pH}$ 7.0-10.0, which suggested potential application of this enzyme in various biotechnological industries. The fibrinolytic enzymes from different Bacillus spp. exhibited maximum activity at $\mathrm{pH}$ 8.0-9.0 (Vishalakshi et al. 2009; Agrebi et al. 2010; Mahajan et al. 2012; Bajaj et al. 2013). The activity and stability of Streptomyces sp. CS684 fibrinolytic enzyme showed shear activity loss in acidic and basic environment (Simkhada et al. 2010). In contrast, fibrinolytic proteases from B. subtilis A26 (Agrebi et al. 2009) and B. amyloliquefaciens An6 (Agrebi et al. 2010) showed stability over a broad range of acidic and alkaline $\mathrm{pH}$. 
Metal ions can influence the activity of enzymes in several ways (Palmer 2001). B. subtilis I-2 protease showed inhibition in the presence of various metal ions. However, B. cereus NS-2 fibrinolytic protease was activated by $\mathrm{Fe}^{2+}$ but inhibited by $\mathrm{Pb}^{2+}$ and $\mathrm{Hg}^{2+}$ (Bajaj et al. 2013). B. subtilis A26 fibrinolytic protease remained unaffected in the presence of $\mathrm{Ca}^{2+}$, got slightly influenced by $\mathrm{Na}^{+}, \mathrm{K}^{+}, \mathrm{Ba}^{2+}, \mathrm{Cu}^{2+}, \mathrm{Mg}^{2+}$ and $\mathrm{Mn}^{2+}$, but significantly inhibited by $\mathrm{Hg}^{2+}$ and $\mathrm{Zn}^{2+}$ (Agrebi et al. 2009). Fibrinolytic activity of $B$. subtilis ICTF-1 protease was activated by $\mathrm{Ca}^{2+}$ and inhibited by $\mathrm{Zn}^{2+}, \mathrm{Fe}^{3+}$ and $\mathrm{Hg}^{2+}$ (Mahajan et al. 2012). EDTA caused inhibition to the activity of B. subtilis I-2 protease. Similarly, fibrinolytic enzymes from B. amyloliquefaciens An6 (Agrebi et al. 2010) and Streptomyces sp. CS684 (Simkhada et al. 2010) have been reported to be inhibited by EDTA.

\section{CONCLUSIONS}

It was concluded that B. subtilis I-2 due to its capability to successfully utilize various agricultural residues as substrates could be of potential use for cost-effective production of fibrinolytic protease. The stability of protease under alkaline $\mathrm{pH}$ suggested its possible applications for detergent industry. Further enhancement of protease production from $B$. subtilis I-2 could be attempted by using statistical optimization approaches and genetic engineering tools.

\section{ACKNOWLEDGEMENTS}

Dr. Bijender Kumar Bajaj gratefully acknowledges the financial support from Indian Council of Medical Research (ICMR Extramural Research Project Ref. No: 5/4/1/EXM/12-NCD-II); Mr. Satbir Singh is highly thankful to the Council of Scientific and Industrial Research (CSIR) for Junior/Senior Research Fellowship. Authors thank the Director, School of Biotechnology University of Jammu, for providing necessary laboratory facilities for accomplishment of this work.

\section{REFERENCES}

Agrebi R, Haddar A, Hajji M, Frikha F, Manni L, Jellouli K, Nasri, M. Fibrinolytic enzymes from a newly isolated marine bacterium Bacillus subtilis A26: characterization and statistical media optimization. Canadian J Microbiol. 2009; 55: 10491061.

Agrebi R, Hmider N, Hajji M, Ktari N, Haddar A, Zouari NH, Nasri M. Fibrinolytic serine protease isolated from Bacillus amyloliquefaciens An6 grown on Mirabilis Jalapa tuber powders. Appl Biochem Biotechnol. 2010; 162: 75-88.

Astrup T, Mullertz S. The fibrin plate method for estimating fibrinolytic activity. Arch Biochem Biophys. 1952; 40: 346-351.

Bajaj BK, Sharma P. An alkali-thermotolerant extracellular protease from a newly isolated Streptomyces sp. DP2. New Biotechnol. 2011; 28: 725-732.

Bajaj BK, Sharma S. Construction of killer industrial yeast Saccharomyces cerevisiae HAU-1 and its fermentation performance. Braz J Microbiol. 2010; 41: 477-485.

Bajaj BK, Singh NP. Production of xylanase from an alkalitolerant Streptomyces sp. $7 \mathrm{~b}$ under solid-state fermentation, its purification, and characterization. Appl Biochem Biotechnol. 2010; 162: 180-188.

Bajaj BK, Wani, MA. Enhanced phytase production from Nocardia sp. MB 36 using agro-residues as substrates: Potential application for animal feed Production. Eng Life Sci. 2011; 11: 620-628.

Bajaj BK, Khajuria YP, Singh VP. Agricultural residues as potential substrates for production of xylanase from alkali-thermotolerant bacterial isolate. Biocatal Agric Biotechnol. 2012; 1: 314-320.

Bajaj BK, Sharma N, Singh S. Enhanced production of fibrinolytic protease from Bacillus cereus NS-2 using cotton seed cake as nitrogen source. Biocatal Agric Biotechnol. 2013; 2: 204-209.

Calik G, Pehlivan N, Kalender N, Ozdamar TH, Calik P. Utilization of pretreated molasses for serine alkaline protease production with recombinant Bacillus species. Chem Eng Commun. 2003; 190: 630-644.

Gessesse A, Rajni HK, Gashe BA. Novel alkaline proteases from alkaliphilic bacteria grown on chicken feather. Enzyme Microbial Technol. 2003; 32: 519524.

Haddar A, Fakhfakh-Zouari N, Hmidet N, Frikh, F, Nasri M, Kamoun AS. Low-cost fermentation medium for alkaline protease production by Bacillus mojavensis A21 using hulled grain of wheat and sardinella peptone. J Biosci Bioeng. 2010; 110: 288294. 
Joshi R, Jan S, Wu Y, MacMahon S. Global Inequalities in Access to Cardiovascular Health Care. J Am Coll Cardiol. 2008; 52: 1817-1825.

Kim J, Kim JH, Choi KH, Kim JH, Song YS, Cha J. Enhancement of the Catalytic Activity of a $27 \mathrm{kDa}$ Subtilisin-Like Enzyme from Bacillus amyloliquefaciens $\mathrm{CH} 51$ by in Vitro Mutagenesis. $J$ Agric Food Chem. 2011; 59: 8675-8682.

Mahajan PM, Nayak S, Lele SS. Fibrinolytic enzyme from newly isolated marine Bacillus subtilis ICTF-1: media optimization, purification and characterization. J Biosci Bioeng. 2012; 113: 307-314.

Mander P, Cho SS, Simkhada JR, Choi,YH, Yoo JC. A low molecular weight chymotrypsin-like novel fibrinolytic enzyme from Streptomyces sp. CS624. Process Biochem. 2011; 46: 1449-1455.

Mukherjee AK, Rai SK. A statistical approach for the enhanced production of alkaline protease showing fibrinolytic activity from a newly isolated Gramnegative Bacillus sp. strain AS-S20-I. New Biotechnol. 2011; 28: 182-189.

Mukherjee AK, Rai SK, Thakur R, Chattopadhyay P, Kar SK. Bafibrinase: A non-toxic, non-hemorrhagic, direct-acting fibrinolytic serine protease from Bacillus sp. strain AS-S20-I exhibits in vivo anticoagulant activity and thrombolytic potency. Biochimie. 2012; 94: 1300-1308.

Palmer T. The Chemical Nature of Enzyme Catalysis, Enzymes: Biochemistry, Biotechnology and Clinical Chemistry. Horwood Publishing Limited, Coll House, Westergate, England, 2001.

Peng Y, Yang X, Zhang Y. Microbial fibrinolytic enzymes: an overview of source, production, properties, and thrombolytic activity in vivo. Appl Microbiol Biotechnol. 2005; 69: 126-132.

Pillai P, Mandge S, Archana G. Statistical optimization of production and tannery applications of a keratinolytic serine protease from Bacillus subtilis P13. Process Biochem. 2011; 46: 1110-1117.
Qureshi AS, Bhutto MA, Khushk I, Dahot MU. Optimization of cultural conditions for protease production by Bacillus subtilis EFRL 01. Afr J Biotechnol. 2011; 10: 5173-5181.

Sambrook J, Maniatis T. Molecular Cloning: A Laboratory Manual, 2nd Edition, Cold Spring Harbor Laboratory Press. 1989.

Shikha Sharan A, Darmwal NS. Improved production of alkaline protease from a mutant of alkalophilic Bacillus pantotheneticus using molasses as a substrate. Bioresource Technol. 2007; 98: 881-885.

Simkhada JR, Mander P, Cho SS, Yoo JC. A novel fibrinolytic protease from Streptomyces sp. CS684. Process Biochem. 2010; 45: 88-93.

Stanbury PF, Whitaker A, Hall SJ. Principles of Fermentation Technology, Butterworth-Heinemann, UK. 1995.

Uesugi Y, Usuki H, Iwabuchi M, Hatanaka T. Highly potent fibrinolytic serine protease from Streptomyces. Enzyme Microbial Technol. 2011; 48: 7-12.

Vishalakshi N, Lingappa K, Amena S, Prabhakar M, Dayanand A. Production of alkaline protease from Streptomyces gulbargensis and its application in removal of stains. Indian J Biotechnol. 2009; 8: 280285.

Wang SH, Zhang C, Yang YL, Diao M, Bai MF. Screening of a high fibrinolytic enzyme producing strain and characterization of the fibrinolytic enzyme produced from Bacillus subtilis LD-8547. World J Microbiol Biotechnol. 2008; 24: 475-482.

Wang SL, Chao CH, Liang TW, Chen CC. Purification and characterization of protease and chitinase from Bacillus cereus TKU006 and conversion of marine wastes by these enzymes. Mar Biotechnol. 2009; 11: 334-344. 